\author{
Население Сибири XVII в.: \\ существующие подходы \\ к проблеме \\ математической модели
}

И.Р. Соколовский*

DOI: $10.31518 / 2618-9100-2019-4-2$

УДК 94(57):51-77

Выходные данные для цитирования:

Соколовский И.Р. Население Сибири XVII в.: существующие подходы к проблеме математической модели // Исторический курьер. 2019. № 4 (6). Статья 2. URL: http://istkurier.ru/data/2019/ISTKURIER-2019-402.pdf

\section{I.R. Sokolovskiy*}

The population of Siberia $17^{\text {th }}$ in the century: the existing approaches to the problem of the mathematical model of population

DOI: $10.31518 / 2618-9100-2019-4-2$

How to cite:

I.R. Sokolovskiy The population of Siberia in the $17^{\text {th }}$ century: the existing approaches to the problem of the mathematical model of population // Historical Courier. 2019. \# 4 (6). Article 2. URL: http://istkurier.ru/data/2019/ISTKURIER2019-4-02.pdf

Abstract. The article dicuseses the problem of mathematical model of population growth in Siberia in the $17^{\text {th }}$ century. Some issues were put forward in our works of 2016.

Several scholars tried to construct a model of population growth of the entire globe in a period of known human history and predict how this growth will develop in the future and the results it could produce. We discuss the works of S.P. Kapitsa and E.D. Grazhdannikov.

One of the first works of this kind was the article by von Foerster, Mora, and Amiot (1960), which, despite its empirical character, had the predictive power for about 30 years.

In 1974 the Novosibirsk researcher E.D. Grazhdannikov tried to put together all the types of equations in one book. He discusses the population dynamics for a minimum four different cases (lack of growth, linear growth, exponential growth and hyperbolic growth).

In 1999 a monograph by S.P. Kapitsa was published, in which he summed up some of his research activities and where he proposed its own periodization of demographic history and substantiated a number of its constants, as well as a number of equations, describing the dynamics of population growth at different stages of human history.

In 2016 we made a number of attempts to select some equations to describe the dynamics of the Russian population of Siberia in the $17^{\text {th }}$ century. we selected three models and assembled them into one table the possible results of these retrospective forecasts.

Keywords: population; Siberia; $17^{\text {th }}$ century; mathematical models; historiography; linear model; hyperbolic model; natural growth.

The article has been received by the editor on 10.08.2019.

Full text of the article in Russian and references in English are available below.

Аннотация. Статья посвящена проблеме построения математической модели роста населения Сибири в XVII веке. В таком виде проблема никогда не ставилась.

Однако различные ученые пытались построить такую модель относительно роста численности населения всего земного шара за известный нам период человеческой истории и спрогнози-

\footnotetext{
* Соколовский Иван Ростиславович, канд. ист. наук, научный сотрудник, Институт истории Сибирского отделения Российской академии наук (Новосибирск, Россия), e-mail: sokolowski@yandex.ru

* Sokolovskiy Ivan Rostislavovich, Candidate of Historical Sciences, Researcher, Institute of History of the Siberian Branch of the Russian Academy of Sciences (Novosibirsk, Russia), e-mail: sokolowski@yandex.ru
} 
ровать, каким образом этот рост будет происходить в будущем и к каким результатам он может привести. Рассматриваются работы С.П. Капицы, Е.Д. Гражданникова и автора статьи.

Одной из первых работ такого рода была работа трех авторов (1960), которая, несмотря на свой эмпирический характер, обладала предсказательной силой в течение примерно 30 лет.

В 1974 г. новосибирский исследователь Е.Д. Гражданников попытался в одной публикации собрать все уравнения, которые описывали динамику населения для минимум четырех разных случаев (отсутствие роста, линейный рост, экспоненциальный рост и гиперболический рост).

В 1999 г. вышла монография С.П. Капицы, в которой подводились некоторые итоги его как минимум семилетней исследовательской деятельности, и где автор предложил собственную периодизацию демографической истории и обосновал ряд ее констант, а также ряд уравнений, описывающих динамику роста численности населения на разных этапах человеческой истории.

В 2016 г. мы предприняли ряд попыток подобрать некоторые уравнения для описания динамики русского населения Сибири в XVII в. В настоящей статье мы отобрали три модели и собрали в одну таблицу возможные результаты этих ретроспективных прогнозов.

Ключевые слова: население; Сибирь; XVII век; математические модели; историография; линейная модель; гиперболическая модель; естественный прирост.

$$
* * *
$$

Историческая наука занимается пониманием исторических явлений, причем это понимание может быть выражено трояким образом. Историк может описать историческое явление в понятиях; если оно поддается количественной оценке, он может дать количественную характеристику явления; и, наконец, историческое явление может быть осмыслено с помощью математической модели. Конечно, хотелось бы воздержаться от полемики по поводу иерархии этих трех видов интерпретации в рамках конкретно исторической статьи, но, увы, полемика в этом случае неизбежна.

Как известно, еще в 1950-е гг. на русском языке были изданы мемуары П. Лафарга, который писал про К. Маркса, что в последний период его жизни «он считал также, что наука только тогда достигает совершенства, когда ей удается пользоваться математикой» ${ }^{1}$. Конечно, это величайшее заблуждение. Наука достигает совершенства тогда, когда она формирует точные и ясные понятия относительно человеческого опыта, которые в точных науках могут быть описаны математическим языком и проверены экспериментально. Но это относится только к точным наукам. В гуманитарных науках уровень понятийной интерпретации явлений является наивысшим. Однако и другие подходы к истории имеют свое право на существование. О чем мы и намерены говорить в данной работе.

Важной особенностью исторического исследования является проблема «нехватки данных». При изучении того или иного исторического процесса, например, динамики народонаселения, историк часто сталкивается с пробелами в числовых рядах, так как данные за определенный промежуток времени или являются утраченными, или вовсе никогда не собирались.

Например, как видно на рис. 1, большая часть историко-демографических данных относительно населения такой хорошо изученной европейской страны как Франция, относится к периоду между 1500 и 2000 г. Те, кто попытается проанализировать динамику населения Франции на временном промежутке в две тысячи лет (от 0 до 2013 г.), те немедленно обнаружат, что на последние 500 лет придется почти 40 \% данных, а не ${ }^{1 / 4}$ их, как было бы, если бы данные

\footnotetext{
1 Лафарг П. Воспоминания о Марксе. М., 1967. С. 10.
} 


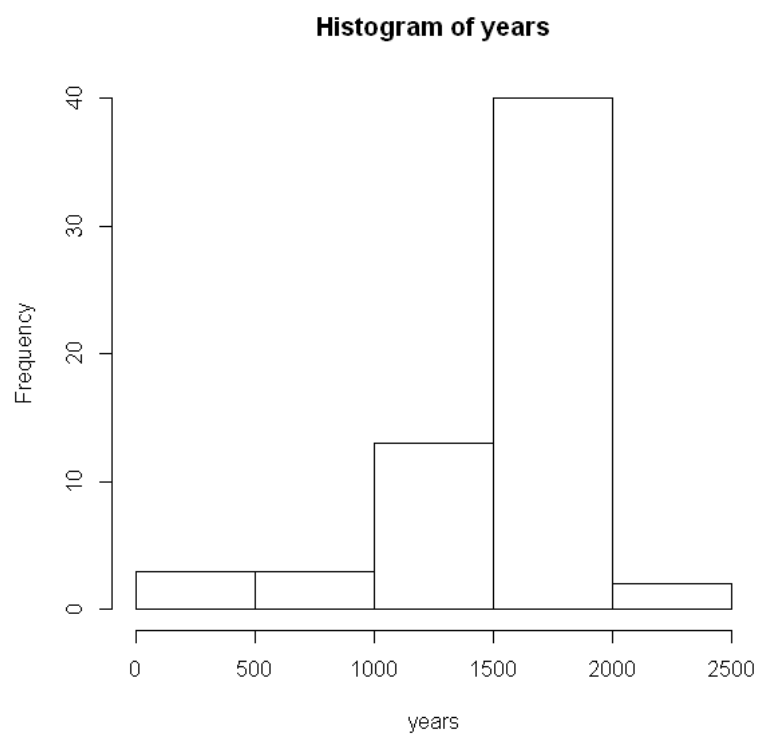

Рис. 1. Полнота данных о численности населения Франции в I-XXI вв.

собирались и сохранились равномерно за все годы. Более того, из работ французских историков мы знаем, что данные после 1500 г. являются более достоверными, чем данные за период, предшествующий этой дате.

Если мы обратимся к частотам распределения значений численности населения в указанный период, то увидим, что более чем в половине известных нам случаев численность населения Франции превывшала 10 млн. чел. (рис. 2), то есть речь шла о достаточно «большом» обществе. И, тем не менее, мы видим тут вопиющую неполноту данных. Что уж говорить об обществах гораздо меньшего размера и гораздо меньшей степени организованности?

Процесс присоединения Сибири к Московскому государству в конце XVI - начале XVII в. характеризовался, в том числе, созданием постоянного русского населения. Изучение его количества, состава, размещения, характера воспроизводства очень важно для характеристики процесса русской колонизации. Однако ситуация нехватки историко-демографических данных, характерная для всех исторических обществ, не делает исключения и для русского населения Сибири в XVII в.

Изучение численности русского населения Сибири в XVII-XVIII вв. сталкивается с теми же двумя проблемами, что и изучение населения Франции: (а) мы имеем дело с неполнотой историко-демографических данных; (б) сам способ получения этих историко-демографических данных подвергается критике со стороны историков.

Нас больше всего интересует наиболее ранний этап освоения Сибири (XVI-XVII вв.). Однако, более достоверные данные относятся к более позднему периоду, к XVIII в. или даже к XIX в. Вот более или менее достоверные данные о численности русского населения Сибири в хронологическом промежутке начала XVIII - середины XIX в.:

1710 г. - ок. 308776 чел.;

1719 г. - ок. 374722 чел.;

1796 г. (V ревизия) - 935079 чел.; 


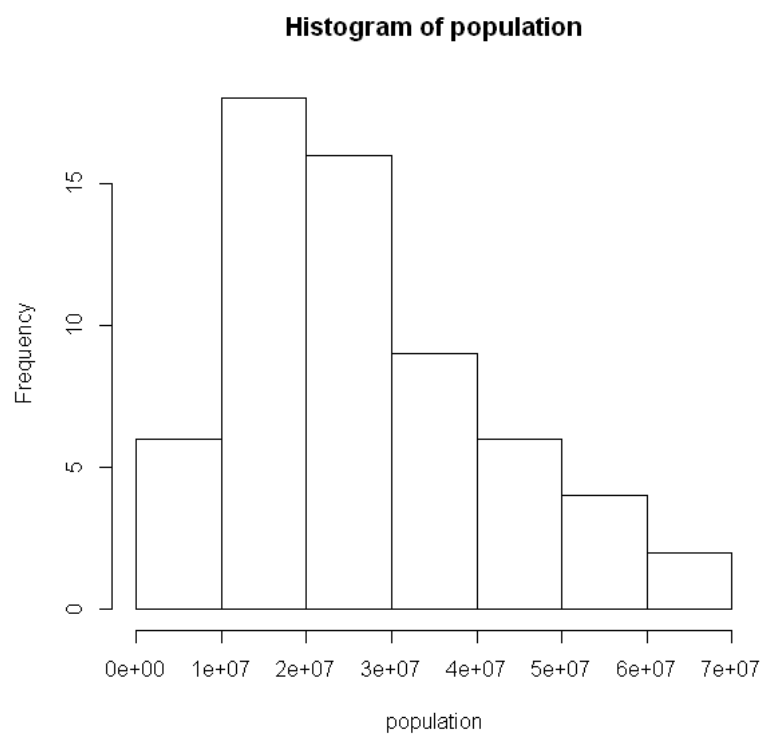

Рис. 2. Частотное распределение данных по численности населения Франции в I-XXI вв.

1858 г. (Х ревизия) -2755564 чел. ${ }^{2}$

Данные за 1710 г. привлекли не только наше внимание (мы написали о них две работы ${ }^{3}$ ), но и нашли отражение в монографии А.С. Зуева, П.С. Игнаткина и В.С. Слугиной, где приводятся численные данные о демографической ситуации в XVII-XVIII вв. Авторы пишут, что к началу 1620-х гг. в Сибири насчитывалось более 20 тыс. русских обоего пола, к началу 1660-х - более 130 тыс., к 1710 г. - более 300 тыс. Они же отмечают, что численность сибирских народов на рубеже XVII-XVIII вв. составляла около 240 тыс. человек. Авторы приходят к выводу, что «таким образом, к началу XVIII в. русские количественно уже заметно преобладали над коренным населением» ${ }^{4}$. Возникает вопрос о методике и источниках подобных подсчетов. Дело в том, что сохранившиеся историко-демографические данные подвергались критике со стороны таких видных историков Сибири как А.Х. Элерт ${ }^{5}$ и Т. С. Мамсик ${ }^{6}$.

Кроме того, особенностью русских источников XVII-XVIII вв. , характеризующих состав, численность, движение русского населения Сибири, является учет только отдельных категорий населения. Русские источники учитывали только самодеятельное мужское население. Незанятое мужское население и все женщины, как вовлеченные в общественнополезный труд, так и несовершеннолетние, источниками учитывались эпизодически. Численность этой категории населения может быть получена только путем экстраполяции немногих имеющихся у нас данных

\footnotetext{
2 «Славянский мир» Сибири: новые подходы в изучении процессов освоения Северной Азии: колл. монография / Под ред. О.Н. Бахтиной, В.Н.Сырова, Е.Е.Дутчак. Томск, 2009. С. 57, 60.

${ }^{3}$ Соколовский И.Р. Русское население Сибири XVII - начала XVIII в. Проблема оценки итогов колонизационного движения // Проблемы исторической демографии Сибири. Сб. науч. трудов. Новосибирск, 2013. Вып. III. С. 30-42; Соколовский И.Р. Население Сибири XVII в.: государственная политика и стихийные процессы. Попытка нового подхода к традиционной проблематике // Сословные и социокультурные трансформации населения Азиатской России (XVII - начало XX века). Сб. мат. Всерос. науч. конф. Новосибирск, 2014. С. $28-37$.

${ }^{4}$ Зуев A.C., Игнаткин П.С., Слугина В.A. Под сень двуглавого орла: инкорпорация народов Сибири в Российское государство в конце XVI - начале XVIII в. Новосибирск, 2017. С. 125

5 Элерт A.X. Экспедиционные материалы Г.Ф. Миллера как источник по истории Сибири. Новосибирск, 1990.

${ }^{6}$ Мамсик Т.С. Экспедиция И.Д. Бухольца и «восстание» ишимских крестьян 1714 г. // Гуманитарные науки в Сибири. 2013. № 2. С.20-24.
} 
или путем вычисления каких-либо поправочных коэффициентов к численности мужского самодеятельного населения. Данные коэффициенты могут быть выбраны на основании опыта, интуиции или других критериев, принятых историком.

Другой особенностью русских источников является отсутствие в XVII в. статистического вида источников. Фактически к таковым могут быть отнесены только результаты переписи 1678 г. Первым полноценным статистическим источником может считаться только перепись 1710 г.

С учетом этой критики сохранившихся источников, мы сформулировали следующую проблему: у нас нет данных о численности всего русского населения Сибири за отдельные периоды XVII в., поэтому если бы мы хотели оценить его численность с помощью какой-нибудь простой математической модели, экстарполирующей известные нам данные одного периода на другие, неизвестные нам, то какую модель следует выбрать, как такая математическая модель могла бы выглядеть?

В своих работах мы уже не раз обсуждали эту проблему и предлагали различные пути ее решения ${ }^{7}$. Все эти публикации были выполнены в условиях внешних технических ограничений, в них нельзя было публиковать график и таблицы, поэтому в данной статье мы повторим основные положения, выдвинутые нами в этих работах. Кроме того, мы добавили сюда ряд новых данных, выдвинули несколько новых предположений, а также исправили некоторые опечатки, возникшие из-за несовершенства технических возможностей публикаторов предыдущих работ.

В настоящее время проблема динамики численности населения Земли является спекулятивной в некоторых кругах. Существует группа ученых, которая пользуется определенными западными историко-демографическимии моделями и выступает с ними на страницах научнопопулярных порталов.

В 1960 году была опубликована статья трех авторов, где делался прогноз роста населения Земли до 2020-х гг. ${ }^{8}$.

Статья носила шуточный характер, но данная функция наиболее точно отражала ситуацию между 1950 и 1990 г., причем именно в эти «концевые» годы теоретически предсказанные значения величины $N_{t}$ (население Земли) совпадали с $N_{d}$, полученными демографами. На 1960 г., год публикации статьи, функция также давала хорошую точность 0,92, расходясь с данными американских демографов всего на $8 \%$.

Расхождение начинает резко нарастать после 1995 г., и в настоящее время предсказанные результаты в 13 млрд. чел. почти в два раза отличаются от актуального результата чуть больше 7 млрд. чел., полученных демографами под эгидой ООН (См. график на рис. 3).

Как мы видим на графике, если с помощью коэффициента $\left(\frac{215000000000}{2026,87-T}\right.$. 0,0021643353142098503) применить данное уравнение к сибирским реалиям, то график получится более плавным, чем был реальный рост населения (см. график, рис. 10). Такая особенность данной модели видна и в таблице 1 и на графике (рис. 3).

Примерные данные для Сибири приведены в таблице 2

\footnotetext{
7 Соколовский И.Р. История русского населения Сибири XVII в. в отечественной историографии второй половины XX - начала XXI в. // Гуманитарные науки в Сибири. 2013. № 2. С. 16-19; Соколовский И.Р.Население Сибири XVIII в.: государственная политика и стихийные процессы. С. 28-37; Соколовский И.Р. Русское население Сибири в XVII в. // Азиатская Россия и сопредельные государства. Новосибирск, 2013. С. 7-16; Соколовский И.Р. Русское население Сибири в 1582-1858 гг.: тенденции и экстраполяции. Актуальные вопросы истории Сибири. Десятые научные чтения памяти профессора А.П. Бородавкина: мат-лы конф. Барнаул, 2015. С. 19-21; Соколовский И.Р. Проблема определения численности русского населения Сибири в XVII в. // Азиатская Россия: проблемы социально-экономического, демографического и культурного развития (XVII-XXI вв.): мат-лы междунар. науч. конф. Новосибирск, 2016. С. 62-67.

${ }^{8}$ H. von Foerster, P. Mora, and L. Amiot Doomsday: Friday, 13 November, A.D. 2026 Science 04 Nov 1960: Vol. 132, Issue 3436, P. 1291-1295.
} 


\begin{tabular}{lr} 
Годы & Коэффициент корреляции \\
\hline 1 & 0,30 \\
1000 & 0,45 \\
1750 & 0,84 \\
1800 & 0,81 \\
1850 & 0,83 \\
1900 & 0,88 \\
1950 & 0,96 \\
1955 & 0,93 \\
1960 & 0,92 \\
1965 & 0,90 \\
1970 & 0,88 \\
1975 & 0,88 \\
1980 & 0,89 \\
1985 & 0,91 \\
1990 & 0,95 \\
1995 & 1,02 \\
2000 & 1,14 \\
2005 & 1,34 \\
2013 & 1,87
\end{tabular}

Таблица 1. Коэффициент корреляции населения мира по данным ООН и по модели.

\begin{tabular}{lr} 
Годы & Рус. нас. Сибири по формуле 1960 г. \\
\hline 1710 & 1468527 \\
1719 & 1511456 \\
1796 & 2015559 \\
1858 & 2755564
\end{tabular}

Таблица 2. Русское население Сибири по модели 1960 г.

В 1974 г. новосибирский исследователь Е.Д. Гражданников сделал попытку представить группу возможных математических моделей роста населения. В работе Е.Д. Гражданникова уделено место обзору всех возможных математических моделей динамики населения ${ }^{9}$.

Уравнение для скорости роста:

$$
\frac{d y}{d t}=0
$$

где $y$ - переменная (в нашем случае численность населения), а $t$ - время.

Формула линейного роста численности населения будет имеет вид:

$$
\frac{d y}{d t}=c_{1}
$$

а уравнение динамики имеет вид:

$$
y=c_{1}\left(t-t_{02}\right)+y_{02},
$$

\footnotetext{
${ }^{9}$ Гражданников Е.Д. Прогностические модели социально-демографических процессов. Новосибирск, 1974.
} 
где

$y_{02}$ - начальное значение показателя, а $t_{02}$ - начальный момент времени, (момент времени, с которого начинается «рост по линейному закону»).

Экспоненииальное уравнение роста имеет вид:

$$
\frac{d y}{d t}=c_{2} y
$$

где $c_{2}$ - константа скорости роста;

тогда уравнение динамики будет иметь вид:

$$
y=y_{03} e^{c_{2}\left(t-t_{03}\right)}
$$

где $y_{03}$ - начальное значение показателя для этапа экспоненциального роста;

$t_{03}$ - начальный момент времени для этапа экспоненциального роста;

Гиперболическое уравнение роста. Уравнение для скорости роста имеет вид:

$$
\frac{d y}{d t}=c_{3} y^{2},
$$

где $c_{3}$ - константа скорости второго порядка.

У равнение динамики выглядит следующим образом:

$$
y^{-1}=c_{3}\left(t_{04}-t\right)+y_{04}^{-1}
$$

или

$$
y=\frac{c_{3}^{1}}{t_{04}^{1}-t},
$$

где $y_{04}$ - конечное значение показателя для гиперболического этапа;

$t_{04}$ - конечный момент времени для гиперболического этапа (момент времени, с которого прекращается рост по гиперболическому закону с данным значением константы $\left.c_{3}\right)$;

$t$ - кажущееся значение момента времени для гиперболического этапа, которое получается, если предположить, что $y_{04}^{-1}=\infty$;

$c_{3}^{1}$, константа $c_{3}^{1}=c_{3}^{-1} 10$.

После чего Е.Д. Гражданников приходит к выводу, что «выражение для скорости роста на трех последних этапах можно объединить в одной формуле вида:

$$
\frac{d y}{d t}=c_{m+1} y^{m}
$$

где $c_{m+1}$ - константа в уравнении для скорости роста, $m$ - порядок скорости роста. Для линейного этапа $m=0$, для экспоненциального $m=1$; для гиперболического $m=2{ }^{11}$.

Создав, таким образом, модель роста численности населения в общем виде, Е.Д. Гражданников уделяет внимание и другим существующим моделям, в частности той, которую он называет «Гиперболический закон роста численности населения земного шара»

Гиперболический закон роста численности населения земного шара $S_{M}=\frac{206960}{2030-t}$.

$S_{M}$ - численность населения земного шара в момент времени $M$ в млн. чел.;

$t$ - любой год от 0 до 2030 г. Среднеквадратичные отклонения для периода $1600-1960$ гг. ${ }^{12}$.

\footnotetext{
${ }^{10}$ Там же. С. 18.

${ }^{11}$ Там же. С. 19.

${ }^{12}$ Там же. С. 23.
} 
Поскольку Е.Д. Гражданников не использует свою модель для моделирования численности населения в прошлом, а ставит своей задачей прогнозирование численности и динамики населения в будущем, и его монография так и называется «Прогностические модели социальнодемографических процессов», то для своих целей он использует историко-демографические данные, которые он черпает из работ известного исторического демографа Б.Ц. Урланиса. Данные которого о численности населения России в историческом прошлом и представлены в монографии Е.Д. Гражданникова в таблицах 15 и $16^{13}$.

В 1999 г. увидела свет работа академика С.П. Капицы ${ }^{14}$. Она была снабжена подзаголовком: «Сколько людей жило, живет и будет жить на Земле».

С.П. Капица пишет, что население мира в момент времени $T$ мы будем харатеризовать числом людей $N(T)$. Это дифференциальное уравнение свяжет основные переменные следующим образом:

$\frac{\partial N}{\partial T}=\overline{F\left(N, T, X, Y, K, \tau, \nabla^{2} N, \ldots\right)} \rightarrow \frac{\partial N}{\partial T}=f(N, K, \tau)$,

где $K$ - масштабный множитель и $\tau$ - масштаб времени,

С.П. Капица находит постоянную относительного роста населения ${ }^{15}$ :

$$
\lim _{\Delta N, \Delta T \rightarrow 0} \frac{\Delta N}{N-N_{1}} \frac{T-T_{1}}{\Delta T}=\frac{d \ln \left|N-N_{1}\right|}{d \ln \left|T-T_{1}\right|}=\alpha .
$$

В формуле (10), где $T$ - момент времени, а $N(T)$ - численность населения в данный момент времени, $C$ и $\alpha-$ суть постоянные.

С.П. Капице, разумеется, известна формула 1960 г., он пишет: «затем Форстер в 1960 г. предложил эмпирическую формулу $C=(187,4 \pm 0,4) \cdot 10^{9}, T_{1}=2027 \pm 5$ и $\alpha=-0,99 \pm 0,009$, обработав методом наименьших квадратов данные о населении мира... до 1960 г.». Далее он отмечает, что «позднее Хорнер предложил аналогичное выражение:

$$
N=\frac{C}{T_{1}-T}=\frac{200 \cdot 10^{9}}{2025-T},
$$

при $\alpha=-1$, что с удивительной точностью описывает рост населения Земли в течении сотен ибо даже многих тысяч лет. Независимо от Хорнера к такому описанию роста пришел и автор (С.П. Капица - И. С.)» ${ }^{16}$.

Динамику численности населения Земли С.П. Капица описывает с помощью трех уравнений.

$$
\begin{gathered}
\frac{\delta N}{\delta T}=\frac{N^{2}}{C}+\frac{1}{\tau}, \\
\frac{\delta N}{\delta T}=\frac{C}{\left(T_{1}-T\right)^{2}}, \\
\frac{\delta N}{\delta T}=\frac{C}{\left(T_{1}-T\right)^{2}+\tau^{2}} .
\end{gathered}
$$

\footnotetext{
${ }^{13}$ Там же. С. 65-66.

14 Капица С.П. Общая теория роста человечества. М., 1999.

${ }^{15}$ Там же. С. 160.

${ }^{16}$ Там же. С. 161-162.
} 
Для автора была очень важна вычисленная им формула демографического перехода:

$$
N=\frac{C}{\tau} \arctan \cot \left(\frac{T_{1}-T}{\tau}\right)
$$

Здесь $T$ - момент времени, а $N(T)$ - численность населения в данный момент времени, $C$ и $\tau$ - постоянные.

Однако она не очень значима для нашего исследования. Во всех формулах приняты значения

$$
C=(185 \pm 1) \cdot 10^{9} \quad T_{1}=2005 \pm 1
$$

$$
K=\sqrt{\frac{C}{\tau}}=64100 \pm 1000
$$

$\tau=45 \pm 1^{17}$.

Таким образом, С.П. Капица поставил проблему роста численности населения Земли в общем виде с учетом пространственного компонента. Он обобщил ряд работ своих предшественников (хотя работы Е.Д. Гражданникова он не упоминал и, скорее всего, не знал про них) и сформулировал свою теорию динамики населения Земли, в которой очень важную роль играет формула демографического перехода и возможной стабилизации численности населения Земли уже в XXI в.

Для обоснования выбора математической модели обратимся опять к примеру Франции. Если мы нанесем все имеющиеся у нас данные о численности ее населения (для удобства работы мы заимствовали эти данные из Википедии), то мы получим картину гиперболического роста, описанную в работах Е.Д. Гражданникова и С.П. Капицы для населения Земли в целом.

На рис. 4 мы видим, что столбчатая диаграмма имеет определенную форму, показывающую резкий рост населения после 1500 г. Очевидно, что этот рост имеет «уступчатый» характер, но все же возникает соблазн проверить, не может ли он быть описан какой-нибудь линейной функцией.

Например, на отрезке между 1930 и 2013 г. рост населения Франции явно тяготеет к линейному.

На рис. 5 мы попытались изобразить график возможной линейной функции с помощью красной прямой линии. $\mathrm{K}$ сожалению, из-за системной ошибки в программе $\mathrm{R}$ результат получился не таким нагладным, как мы бы хотели. Конечно, иллюстрацию можно переделать вручную, но мы сохранили все как есть из методологических соображений, чтобы наш читатель имел ввиду, что ошибка может иметь не только человеческий, но и программный характер. Функция, изображенная на иллюстрации, имеет следующий вид:

$$
y=(345890,17857143 \cdot x)-631528990,5714286
$$

На рис. 6 видно, что чем короче отрезок времени, тем проще описать исследуемый объект с помощью линейной функции. Так, синяя прямая линия показывает, что на отрезке с 1960 по 2013 г. рост населения приобрел почти линейный характер.

\footnotetext{
${ }^{17}$ Там же. С. 163-164.
} 


\begin{tabular}{lrrrrr} 
& 1582 & 1710 & 1719 & 1796 & 1858 \\
\hline Исторические данные, чел. & 0 & 308776 & 374722 & 935079 & 2755564 \\
$y=2412 x-3816278$ & 0,0 & 308776,0 & 330486,8 & 516234,9 & 665798,2 \\
$y=7327 x-12220964$ & $-629127,9$ & 308770,3 & 374716,3 & 938921 & 1393215,1 \\
$y=29362 x-51800260$ & $-5348532,6$ & $-1590112,1$ & $-1325848,1$ & 935076,7 & 2755561,6
\end{tabular}

Таблица 3. Численность населения Сибири согласно линейным моделям

Результаты этого небольшого эксперимента вдохновили нас на мысль подобрать формулу, которая бы описывала рост населения Сибири в XVI-XIX вв. с помощью какого-нибудь линейного уравнения.

Если мы попытаемся построить модель линейной регрессии только для точек 1582 и 1710 г., то получим уравнение вида:

$$
y=2412,3125 x-3816278,375 .
$$

Это будет означать, что, согласно модели 18, ожидаемая численность русского населения Сибири в 1626 г. не должна превышать 106142 чел. (обоего пола), а в 1660 г. - 181150 чел. (обоего пола). По нашим оценкам, на 1626 г. в Сибири проживало около 3 тыс. казаков (до 15 тыс. с членами семей) и примерно в 10 раз большее число крестьян (до 150 тыс. с членами семей ${ }^{18}$. Таким образом, для короткого промежутка времени (примерно сто лет), такая модель кажется более или менее реалистичной.

Но если мы попытаемся добавить в эту модель чуть более долгий отрезок времени, то эффективность модели изменится самым драматическим образом. Для учета периода 1710-1719 гг. составим уравнение линейной регрессии следующего вида:

$$
y=7327,33 x-12220964 .
$$

Получается, что согласно модели линейной регрессии для точек 1710 и 1719 г. (19), ожидаемая численность русского населения Сибири была равна нулю уже в 1667-1668 гг., а это попросту абсурдно, так как противоречит всем имеющимся у нас историческим и историкодемографическим данным.

Если мы построим модель линейной регрессии, учитывая точки 1796 и 1858 г., то получим уравнение вида:

$$
y=29362,66 x-51800260,68 .
$$

При подстановке конкретных числовых значений в это уравнение мы получим, что согласно этой модели ожидаемая численность русского населения Сибири была равна нулю уже в 1756 г., что еще более абсурдно, чем в предыдущей модели 19.

График для модели 20 изображен на рис. 9.

Из табл. легко можно сделать два вывода. Все линейные модели более или менее адекватны на временном промежутке в 100 лет, но на более долгом промежутке дают слишком большое расхождение с уже известными историческими и историко-демографическими данными.

Таким образом, еще в работах 2016 г. мы выяснили, что, несмотря на соблазнительность пути, описать динамику численности населения Сибири с помощью линейной функции, это

\footnotetext{
${ }^{18}$ Первое столетие сибирских городов XVII век. Новосибирск, 1996. С. 51.
} 


\begin{tabular}{rrrrrrr} 
& Мин. & 1й кв. & Медиан. & Сред. & 3-й кв. & Макс. \\
\hline Историч. данные & 0 & 308800 & 374700 & 874800 & 935100 & 2756000 \\
$y=2412 x-3816278$ & 0 & 308800 & 330500 & 364300 & 516200 & 665800 \\
$y=7327 x-12220964$ & -629100 & 308800 & 374700 & 477300 & 938900 & 1393000 \\
$y=29362 x-51800260$ & -5349000 & -1590000 & -1326000 & -914800 & 935100 & 2756000
\end{tabular}

Таблица 4. Статистические характеристики трех линейных моделей

можно сделать только на очень небольшом промежутке времени, причем с очень маленькой точностью ${ }^{19}$.

Для наглядности сведем данные обо всех четырех моделях в одну таблицу.

Как видим из таб. , колонка «Сред.» показывает среднее значение для всех моделей, которое всякий раз оказывается разным.

На рис. 10 все три линейные модели представлены в виде диаграмм размаха («ящиков с усами»), которые наглядно представлют несовместимость их с исходными данным, представленными в крайней левой части графика. Картина более, чем красноречивая: чем больше промежуток времени, тем больше линейная модель расходится с имеющимися у нас историкодемографическими данными.

Поскольку производная функции находится по известной школьной формуле:

$$
y^{\prime}=\lim _{\Delta x \rightarrow 0} \frac{\Delta y}{\Delta x},
$$

то для линейныйх функций вида $y=a x+b$ она, очевидно, всегда равна $a$, то в случае трех линейных моделей производная принимает значения 2 412, 7327 и 29 362, соотвественно. Из этого уже видно, что эти модели полностью несовместимы друг с другом.

Попытки построить нелинейные модели динамики численности русского населения Сибири, показывают, что они могут лучше связать имеющиеся у нас числовые данные, но противоречат имеющимся у нас историческим и историко-демографическим сведениям, ибо где у нас нет количественных данных о численности русского населения Сибири, у нас есть качественные данные о его наличии или отсутствии.

Математическая модель роста численности русского населения Сибири в XVII в. является возможной, так как у нас есть «нулевая точка отсчета»-1582 г., до которого русское население в Сибири либо отсутствовало, либо было совершенно незначительным.

Показательная регрессионная функция, представленная на рис. 11, описывается уравнением вида:

$$
y=0,0126 \cdot 1,01^{x}
$$

, однако она проходит через точку 0 не в 1582 г., что противоречит историческим данным.

Если же мы попытаемся построить такую модель, чтобы функция принимала значение 0 в точке $x=1582$, и, одновремено, была бы близка ко всем другим известным нам историкодемографическим данным, то лучше всего для этого подходит полиминальная регрессионная функция

Однако данная функция при $\mathrm{x}=1660$, принимает отрицательные значения, что противоречит имеющимся у нас историческим данным (см. рис. 12).

\footnotetext{
19 Соколовский И.Р. Русское население Сибири в 1582-1858 гг.: тенденции и экстраполяции С. 19-21; Соколовский И.Р. Проблема определения численности русского населения Сибири в XVII в. С. 62-67.
} 


\begin{tabular}{lrrrr} 
Годы & Ист.данные. & Лин. & Проц.. & модель 1960 г. \\
\hline 1582 & 0 & 0,0 & 23276,27 & 0,0 \\
1710 & 308776 & 308776,0 & 308696,00 & 422531,1 \\
1719 & 374722 & 330486,8 & 370224,41 & 465460,8 \\
1796 & 935079 & 516234,9 & 1753031,39 & 969563,3 \\
1858 & 2755564 & 665798,2 & 6131370,91 & 1709568,3
\end{tabular}

Таблица 5. Сравнение фактических данных о населени с модельными

Таким образом, полиминальная регрессионная модель вида:

$$
y=55,5754 x^{2}-181939,3702+14878452,9784,
$$

прекрасно демонстрирует нам, что не все, что красиво с математической точки зрения, имеет смысл с точки зрения изучения истории.

Еще один способ описать прирост населения - это учесть фактор естественного прироста. По историческим источникам мы можем наблюдать прирост в 65946 чел. за девять лет (по 7327 чел. в год с 1710 по 1719 г.). Расхождение между данными 1719 г. и данными 1710 г. составляет примерно 21 \%, если бы это были данные за один и тот же год, то их можно было бы считать погрешностью. Но поскольку речь идет о временном промежутке почти в 10 лет, то это естественнъй прирост населения. Таким образом, при естественном приросте в $2 \%$ рост русского населения Сибири в XVI-XVII в. описывался бы формулой:

$$
y=0,0000000003105 \cdot\left(1,0204^{x}\right)
$$

однако для этого численность русского населения Сибири в 1582 г. должна была бы быть равна 23 тыс. чел. Таким образом, можно предположить, что на раннем этапе заселения Сибири русскими, а также в XVIII в. коэффициент естественного прироста был меньше 2 \%. Можно построить и другие модели, где постоянный коэффициент естественного прироста был бы $1 \%$ и меньше.

Вторым недостатком подобной модели является то, что в более отдаленной перспективе она должна была дать к 1858 г. численность населения в 6131370 чел., тогда как исторически достигнутая численность населения была 2755564 чел., почти в три раза меньше теоретического показателя.

Предпринятая нами попытка построить линейную регрессионную модель общего прироста русского населения Сибири XVI-XIX вв., где общий прирост - это алгебраическая сумма результатов естественного и механического прироста населения - потерпела неудачу. Между 1582 и 1858 гг. накопление было столь значительным, что математическая модель должна быть построена с помощью более сложных формул, например, с учетом естественного прироста (принимаемого, ради простоты модели, как постоянная величина).

На более коротком отрезке времени в период с 1582 по 1710 г. линейная регрессия дает более реалистическую картину.

Промежуток между 1710-1719 гг. показывает, что показатель естественного прироста населения Сибири вполне мог быть 2 \%, но, видимо, был все же меньше, и общий прирост шел и за счет механического движения населения, зафиксированного в многочисленных источниках. 


\begin{tabular}{lrrr} 
Годы & Линайная м. & $2 \%$. & фон Ферст. \\
\hline 1600 & 43421,62 & 33479,70 & 44106,92 \\
1625 & 103729,44 & 55468,03 & 111921,30 \\
1650 & 164037,25 & 91897,56 & 188732,73 \\
1675 & 224345,06 & 152252,79 & 276458,91 \\
1700 & 284652,88 & 252247,28 & 377604,21
\end{tabular}

Таблица 6. Сравнение трех моделей населения Сибири в XVII в.

Как всякий количественный процесс, прирост населения может быть описан с помощью какой-либо математической функции, которая хотя бы и не точно, но предсказывает численность населения в тот или иной период времени.

Эвристическая ценность такого рода математической модели заключается в том, что, не имея фактических данных, мы с помощью такой функции можем определить направление поиска.

Сама по себе такая математическая модель не может быть конечным результатом исследования. Она обладает целым рядом существенных недостатков: 1) схематизмом, упрощенчеством, 2) иллюстративностью (низкой эвристической ценностью), 3)может содержать существенные ошибки в тех случаях, когда речь идет о каких-то трудно прогнозируемых и редких событиях.

Однако, наличие такой модели позволяет прогнозировать численность населения в изучаемый период, что позволяет подвергнуть корректировке направления поиска. Например, если расхождение между теоретически предсказанными и полученными реально данными очень велико, исследователь должен направить свои усилия на поиск дополнительных исторических источников.

Без определения численности русского населения Сибири невозможно характеризовать процесс русской колонизации края, его истоки, этапы, характер, результаты. Несмотря на терпимую сохранность первичных учетных документов по истории русского самодеятельного мужского населения Сибири XVII в., мы фактически не имеем статистических источников по данной проблеме. У нас нет сводных статистических данных хотя бы за ряд лет XVII в. Фактически за весь XVII век у нас есть только данные переписи 1678 г. Каким-то образом, с поправкой на начало Петровских реформ, сибирскую ситуацию конца XVII в. отражают данные переписи 1710 г. Однако к обоим документам имеются претензии исследователей. K документам 1678 г. более обоснованные. Ранее нами проведена оценка внутренних отношений данных 1710 г. (распределение по полам в различных регионах, распределение населения по различным регионам), которая показала, что, в целом, данные 1710 г. отражают реальную картину (снижение доли женщин при движении в восточном направлении, увеличение населенности территории русскими при движении в западном направлении). Ранее нами показано, что ошибка не может составлять больше определенной величины (в пределах 15 \%). В данной статье нами показано, что простые модели описывают ситуацию только на коротких промежутках времени. Более сложные модели (Х. фон Ферстера, П. Мора и Л. Амиот (1960), Е.Д. Гражданникова, С.П. Капицы) имеют ограниченное применение.

Мы пришли к выводу, что исследование численности русского населения Сибири XVII в. может быть проведено двумя путями. Либо путем суммирования данных первичных учетных 
документов («окладные», «переписные», «дозорные» и прочие «книги»), либо создания математических моделей, когда рост населения за известный период экстраполируется нами на более ранний период, статистические данные о котором не сохранились. На самом деле, следует идти двумя этими путями. Сначала надо получить теоретические данные на основании математической модели, а потом попытаться проверить, насколько эти результаты подтверждаются или опровергаются историческими источниками.

\section{Лuтература}

H. von Foerster, P. Mora, and L. Amiot Doomsday: Friday, 13 November, A.D. 2026 Science 04 Nov 1960: Vol. 132, Issue 3436, P. 1291-1295.

Гражданников Е.Д. Прогностические модели социально-демографических процессов. Новосибирск: Наука, 1974. 112 с.

Зуев А.С., Игнаткин П.С., Слугина В.А. Под сень двуглавого орла: инкорпорация народов Сибири в Российское государство в конце XVI - начале XVIII в. Новосибирск: ИПЦ НГУ, 2017. $444 \mathrm{c}$.

Капица С.П. Общая теория роста человечества. М.: Наука, 1999. 120 с.

Лафарг П. Воспоминания о Марксе. М.: Политиздат, 1967. 32 с.

Мамсик Т.С. Экспедиция И.Д. Бухольца и «восстание» ишимских крестьян 1714 г. // Гуманитарные науки в Сибири. 2013. № 2. С. 20-24.

Первое столетие сибирских городов XVII век / Отв.ред. Н.Н. Покровский; Подгот.: Н.Д. Зольникова, А.И. Мальцев, Д.Я. Резун и др. Новосибирск, 1996. 190 с.

«Славянский мир» Сибири: новые подходы в изучении процессов освоения Северной Азии: колл. монография / Под ред. О.Н. Бахтиной, В.Н.Сырова, Е.Е.Дутчак. Томск: Изд. ТГУ, 2009. 218 c.

Соколовскиц И.Р. Русское население Сибири в XVII-начале XVIII веков. Проблема оценки итогов колонизационного движения // Проблемы исторической демографии Сибири. Сб. науч. трудов. Новосибирск: Параллель, 2013. Вып. III. С. 30-42.

Соколовский И.Р. История русского населения Сибири XVII в. в отечественной историографии второй половины XX-начала XXI в. // Гуманитарные науки в Сибири. 2013. № 2. С. 16-19.

Соколовскиц И.Р. Русское население Сибири в XVII в. // Азиатская Россия и сопредельные государства. Сборник научных трудов / Под ред. С.А. Папкова, К. Тэраямы. Новосибирск: Параллель, 2013. С. 7-16.

Соколовский И.Р. Население Сибири XVIII в.: государственная политика и стихийные процессы. Попытка нового подхода к традиционной проблематике // Сословные и социокультурные трансформации населения Азиатской России (XVII - начало XX века) Всеросс. научн. конф. / Отв. ред. М.В. Шиловский. Новосибирск: Параллель, 2014. С. 28-37.

Соколовский И.Р. Русское население Сибири в 1582-1858 гг.: тенденции и экстраполяции Актуальные вопросы истории Сибири. Десятые научные чтения памяти профессора А.П. Бородавкина: мат-лы конф. / Под ред. В.А. Скубневского, К.А. Пожарской. Барнаул: Изд-во Алт. ун-та, 2015. С. 19-21.

Соколовский И.Р. Проблема определения численности русского населения Сибири в XVII в. // Азиатская Россия: проблемы социально-экономического, демографического и культурного развития (XVII-XXI вв.): мат-лы междунар. науч. конф. Новосибирск: Параллель, 2016. С. 62-67.

Элерт A.X. Экспедиционные материалы Г.Ф. Миллера как источник по истории Сибири. / Ред. ч.-кор. АН СССР Н.Н. Покровский. Новосибирск: Наука, Сибирское отделение, 1990. $246 \mathrm{c}$. 


\section{References}

H. von Foerster, P. Mora, and L. Amiot Doomsday: Friday, 13 November, A.D. 2026 Science 04 Nov 1960: Vol. 132, Issue 3436, P. 1291-1295.

Grazhdannikov E.D. Prognosticheskie modeli social'no-demograficheskih processov [Predictive models of socio-demographic processes]. Novosibirsk, Nauka, 1974. 112 p.

Zuev A.S., Ignatkin P.S., Slugina V.A. Pod sen' dvuglavogo orla: inkorporacija narodov Sibiri v Rossijskoe gosudarstvo $\mathrm{v}$ konce XVI - nachale XVIII v. [Under the canopy of a two-headed eagle: incorporation of the peoples of Siberia into the Russian state at the end of the $16^{\text {th }}$ and beginning of the $18^{\text {th }}$ centuries]. Novosibirsk, IPC NGU, 2017. 444 p.

Kapica S.P. Obshhaja teorija rosta chelovechestva [The general theory of growth of world population]. Moscow, Nauka, 1999. 120 p.

Lafarg P. Vospominanija o Markse [Memoirs about Marx]. Moscow, Politizdat, 1967. 32 p.

Mamsik T. S. Jekspedicija I. D. Buhol'ca i svosstanieï ishimskih krest'jan 1714 g. [The Expedition of I. D. Bukholts and the Rebellion of Ishim Peasants in 1714] // Gumanitarnye nauki v Sibiri. 2013. \# 2. P. 20-24.

Pervoe stoletie sibirskih gorodov. XVII vek [The First Century of Siberian Cities. $17^{\text {th }}$ Century] . / Ed. N.N.Pokrovskij; Co-authors: N.D.Zol'nikova, A.I.Mal'cev, D.Ja.Rezun et al. Novosibirsk, 1996. 190 p.

"Slavjanskij mir" Sibiri: novye podhody v izuchenii processov osvoenija Severnoj Azii [Slavic World of Siberia: new approaches to the study of the development processes of North Asia] / Ed O.N. Bahtina, V.N. Syrova, E.E. Dutchak. Tomsk, Izd. TGU, 2009. 218 p.

Sokolovski I.R. Russkoe naselenie Sibiri v XVII-nachale XVIII vekov. Problema ocenki itogov kolonizacionnogo dvizhenija [The Russian population of Siberia in the $17^{\text {th }}$ and the beginning of the $18^{\text {th }}$ centuries. The problem of evaluating the results of the colonization movement] // Problemy istoricheskoj demografii Sibiri. Sbornik nauchnyh trudov. Novosibirsk, Parallel', 2013. Vypusk III. P. 30-42.

Sokolovski I.R. Istorija russkogo naselenija Sibiri XVII v. v otechestvennoj istoriografii vtoroj poloviny XX -nachala XXI v. [The history of the Russian population of Siberia in the $17^{\text {th }}$ century in domestic historiography of the second half of the $20^{\text {th }}$ and the beginning of the $21^{\text {th }}$ ] / Gumanitarnye nauki v Sibiri. 2013. \# 2. P. 16-19.

Sokolovski I.R. Russkoe naselenie Sibiri v XVII v. [Russian population of Siberia in the $17^{\text {th }}$ century] // Aziatskaja Rossija i sopredel'nye gosudarstva. Sbornik nauchnyh trudov / Ed. S.A. Papkov, K. Tjerajama. Novosibirsk, Parallel', 2013. P. 7-16.

Sokolovski I.R. Naselenie Sibiri XVIII v.: gosudarstvennaja politika i stihijnye processy. popytka novogo podhoda $\mathrm{k}$ tradicionnoj problematike [Population of Siberia of the $18^{\text {th }}$ century: state policy and spontaneous processes. An attempt to a new approach to traditional issues] // Soslovnye i sociokul'turnye transformacii naselenija Aziatskoj Rossii (XVII nachalo XX veka). Vserossijskaja nauchnaja konferencija. Institut istorii SO RAN / Ed. M.V. Shilovskij. Novosibirsk, Parallel', 2014. P. 28-37.

Sokolovski I.R. Russkoe naselenie Sibiri v 1582-1858 gg.: tendencii i jekstrapoljacii Aktual'nye voprosy istorii Sibiri [The Russian population of Siberia in 1582-1858: trends and extrapolations] // Desjatye nauchnye chtenija pamjati professora A.P. Borodavkina : materialy konferencii / Ed. V.A. Skubnevskij, K.A. Pozharskaja. Barnaul, Izd-vo Alt. un-ta, 2015. P. 19-21.

Sokolovski I.R. Problema opredelenija chislennosti russkogo naselenija Sibiri v XVII v. [The problem of determining the size of the Russian population of Siberia in the $17^{\text {th }}$ century] // Aziatskaja Rossija: problemy social' no-jekonomicheskogo, demograficheskogo i kul'turnogo razvitija (XVIIXXI vv.): materialy mezhdunar. nauch. konf. Novosibirsk, Parallel', 2016. P. 62-67. 
Elert A.H. Ekspedicionnye materialy G.F.Millera kak istochnik po istorii Sibiri [Expeditionary materials of G.F. Miller as a source on the history of Siberia] / Ed. N.N. Pokrovskij. Novosibirsk, Nauka, Sibirskoe otdelenie, 1990. 246 p.

Статья поступила в редакиию 10.08.2019 2. 


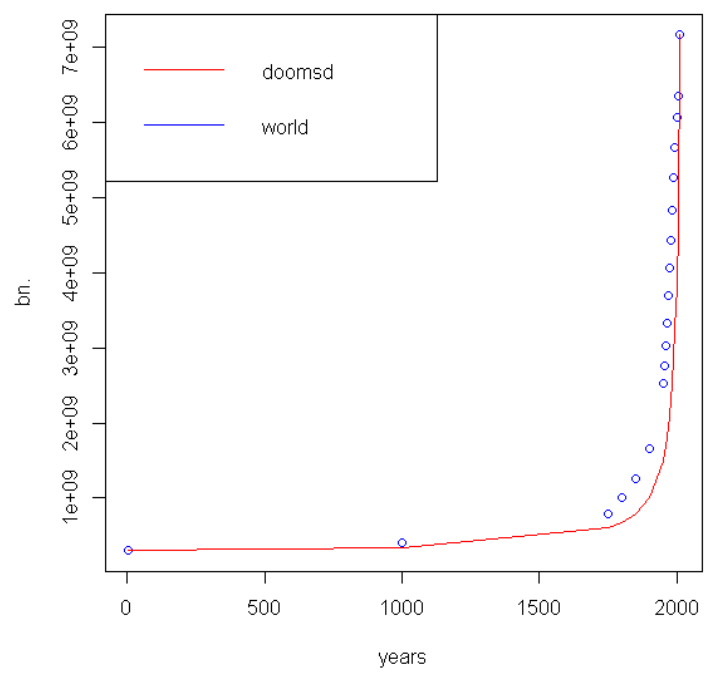

Рис. 3. Коэффициент корреляции для модели и данных ООН

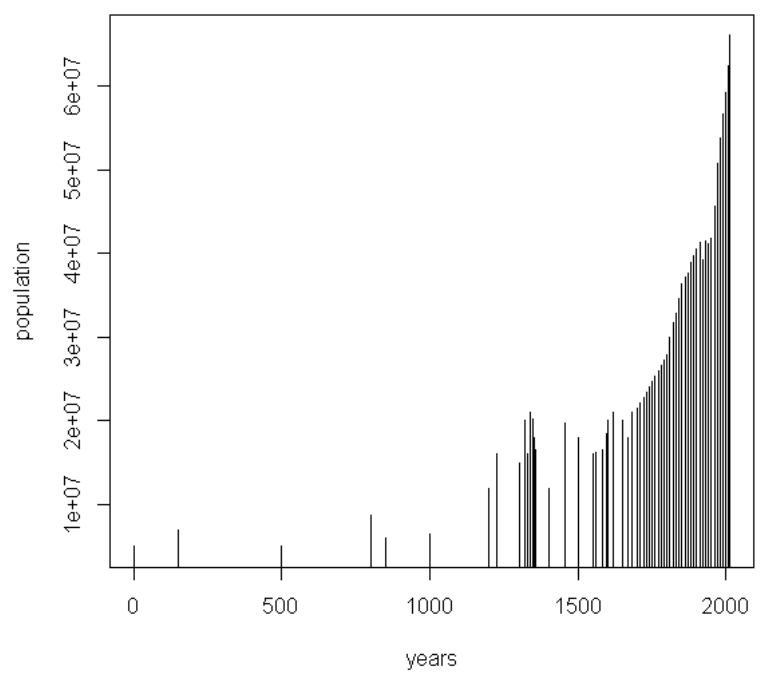

Рис. 4. Численности населения Франции в 1-2013 гг. 


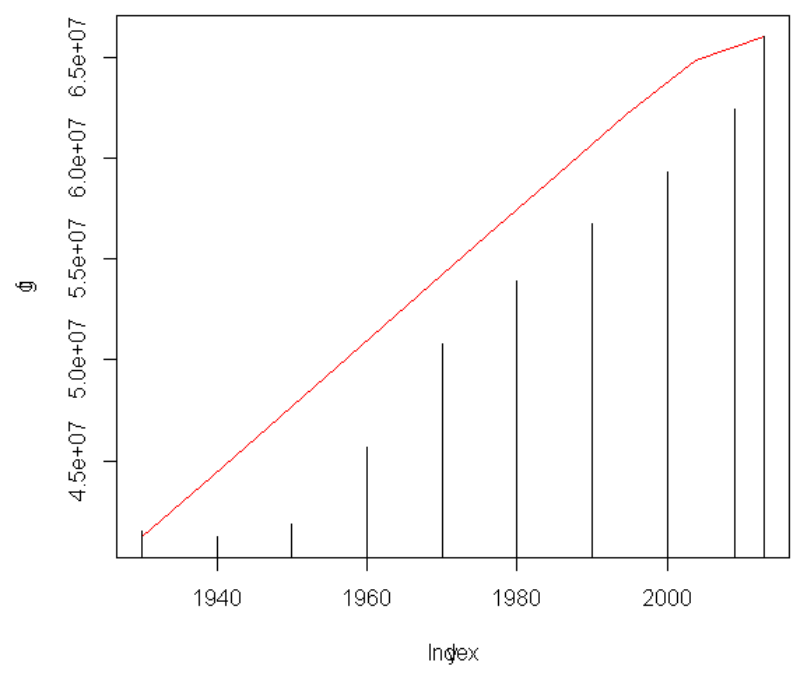

Рис. 5. Численности населения Франции в 1930-2013 гг.

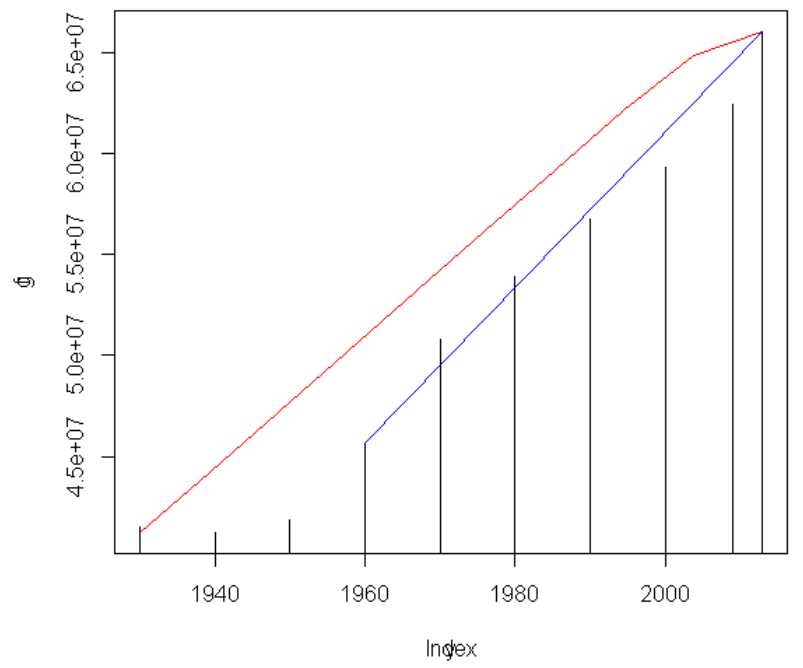

Рис. 6. Численности населения Франции в 1930-2013 гг. Две модели (в т.ч. $y=$ $(345890,17857143 x)-631528990,5714286)$. 


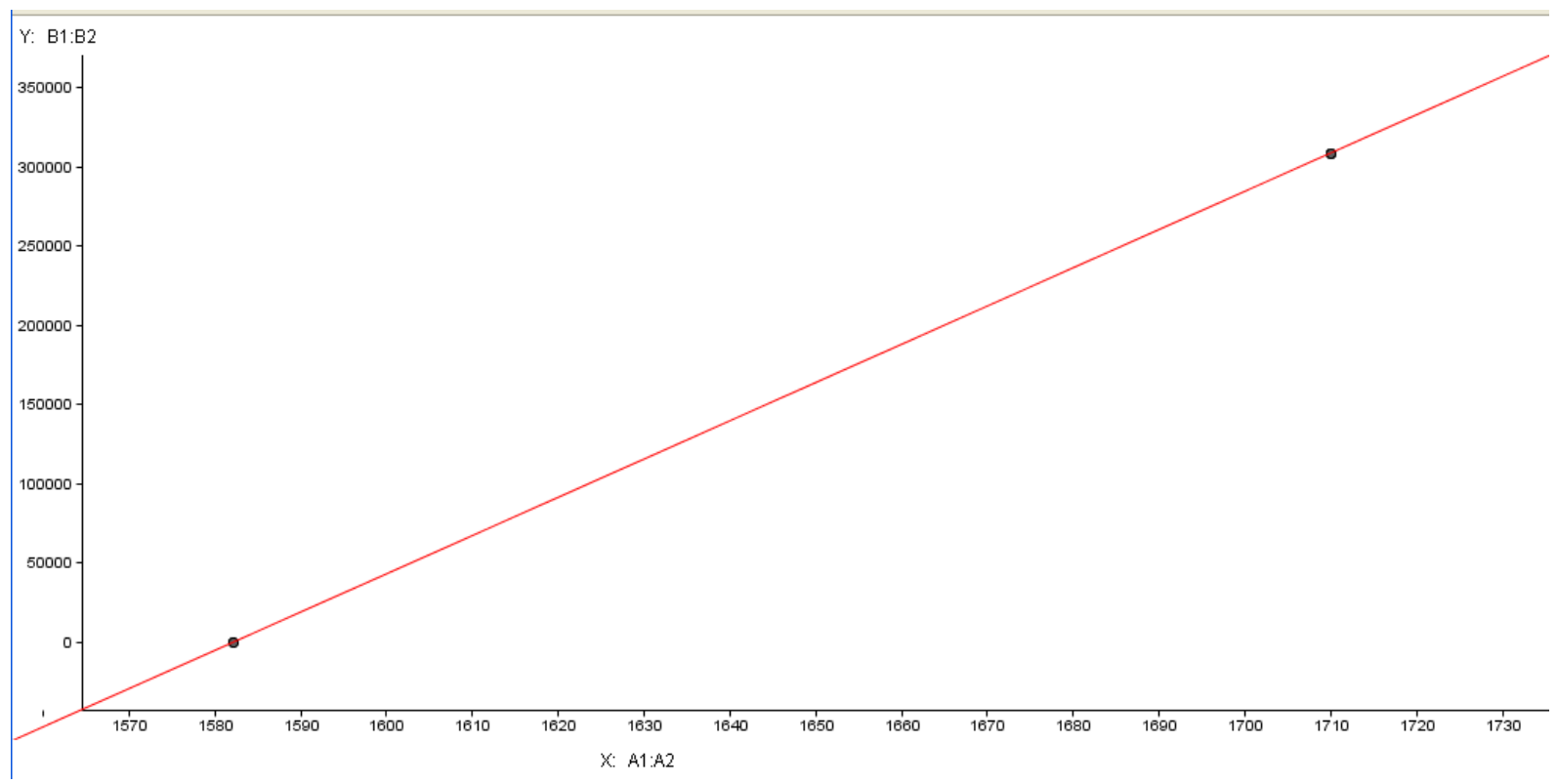

Рис. 7. График для уравнения $y=2412,3125 x-3816278,375$

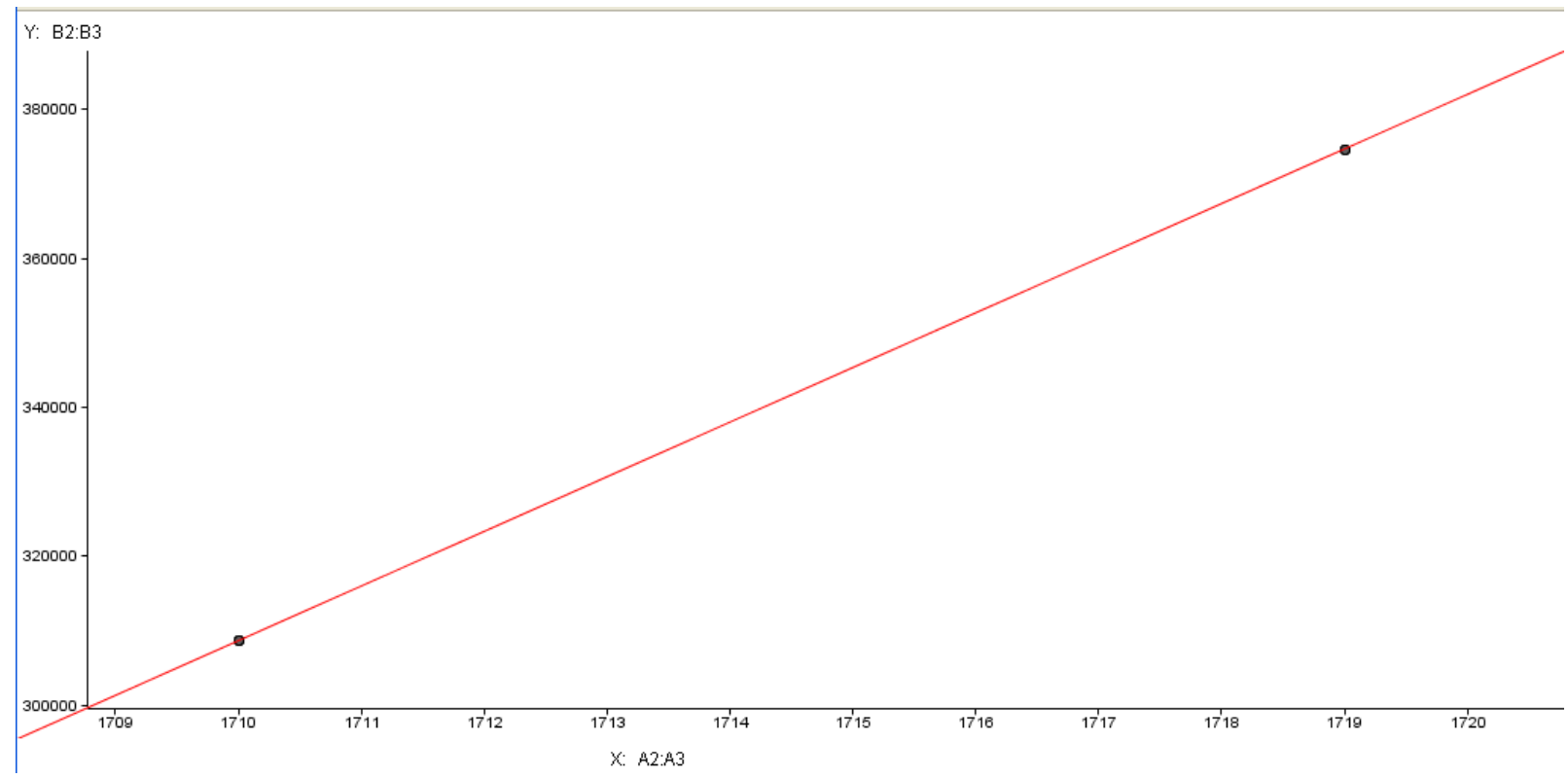

Рис. 8. График для уравненияу $=7327,33 x-12220964$ 


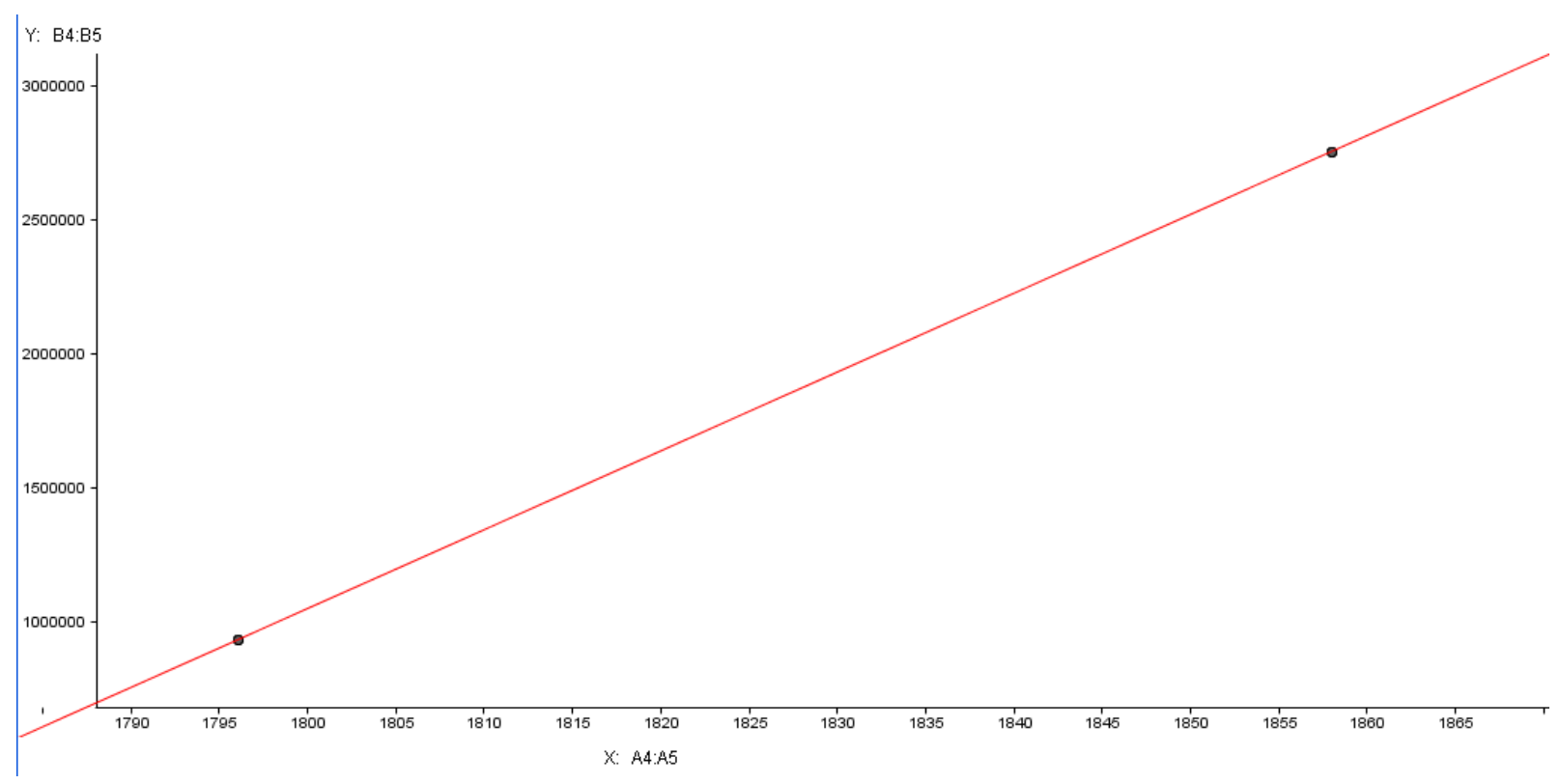

Рис. 9. График уравнения $y=29362,66 x-51800260,68$

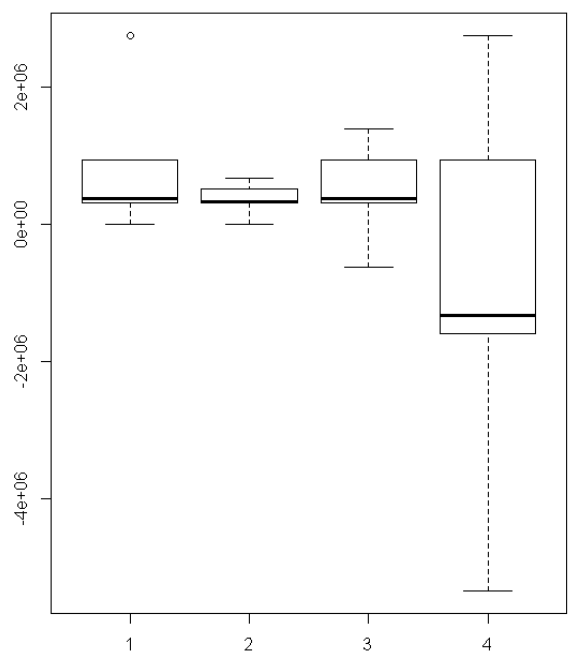

Рис. 10. Три модели и исторические данные (слева) 


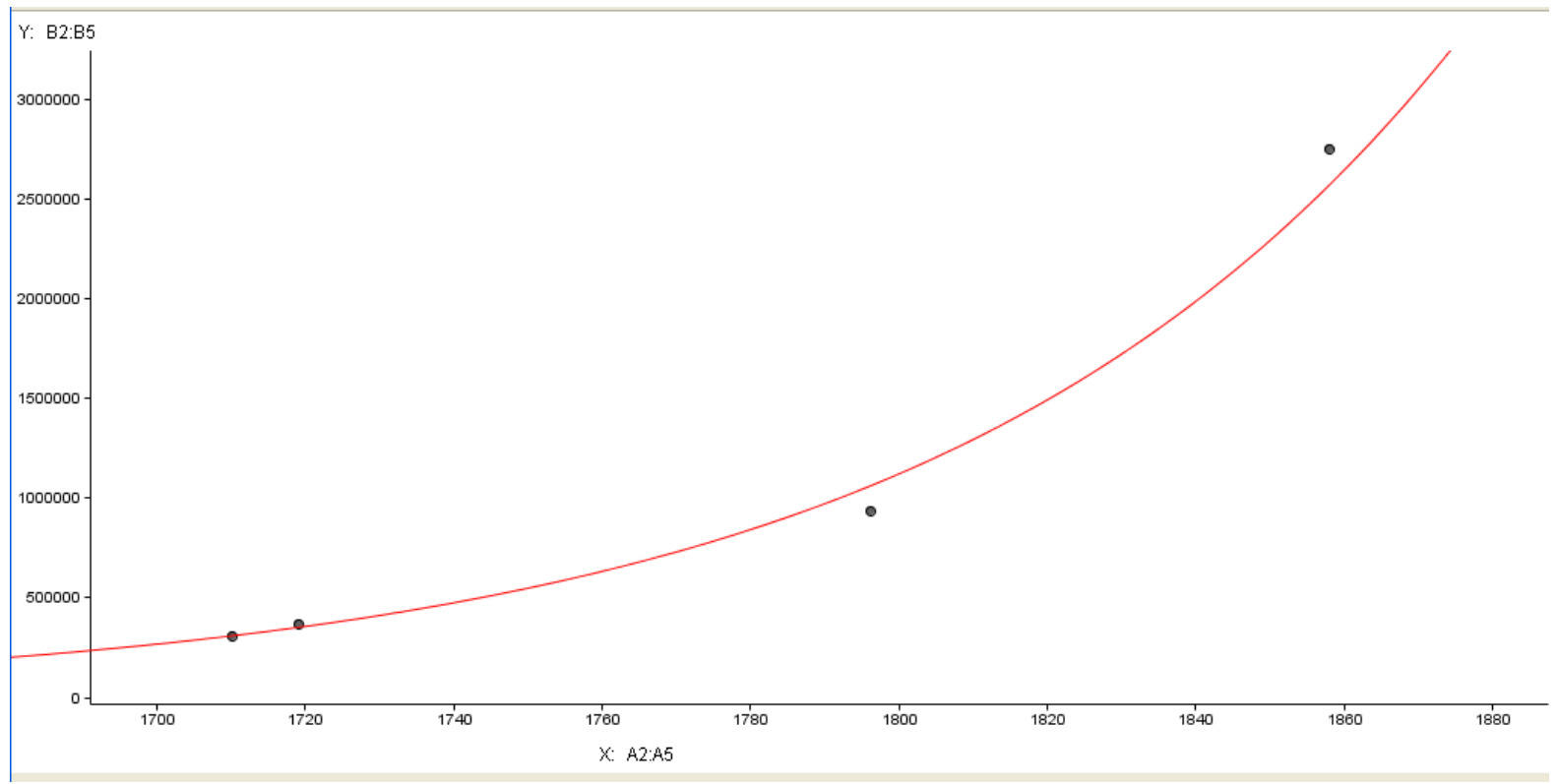

Рис. 11. График уравнения $y=0,0126 \cdot 1,01^{x}$

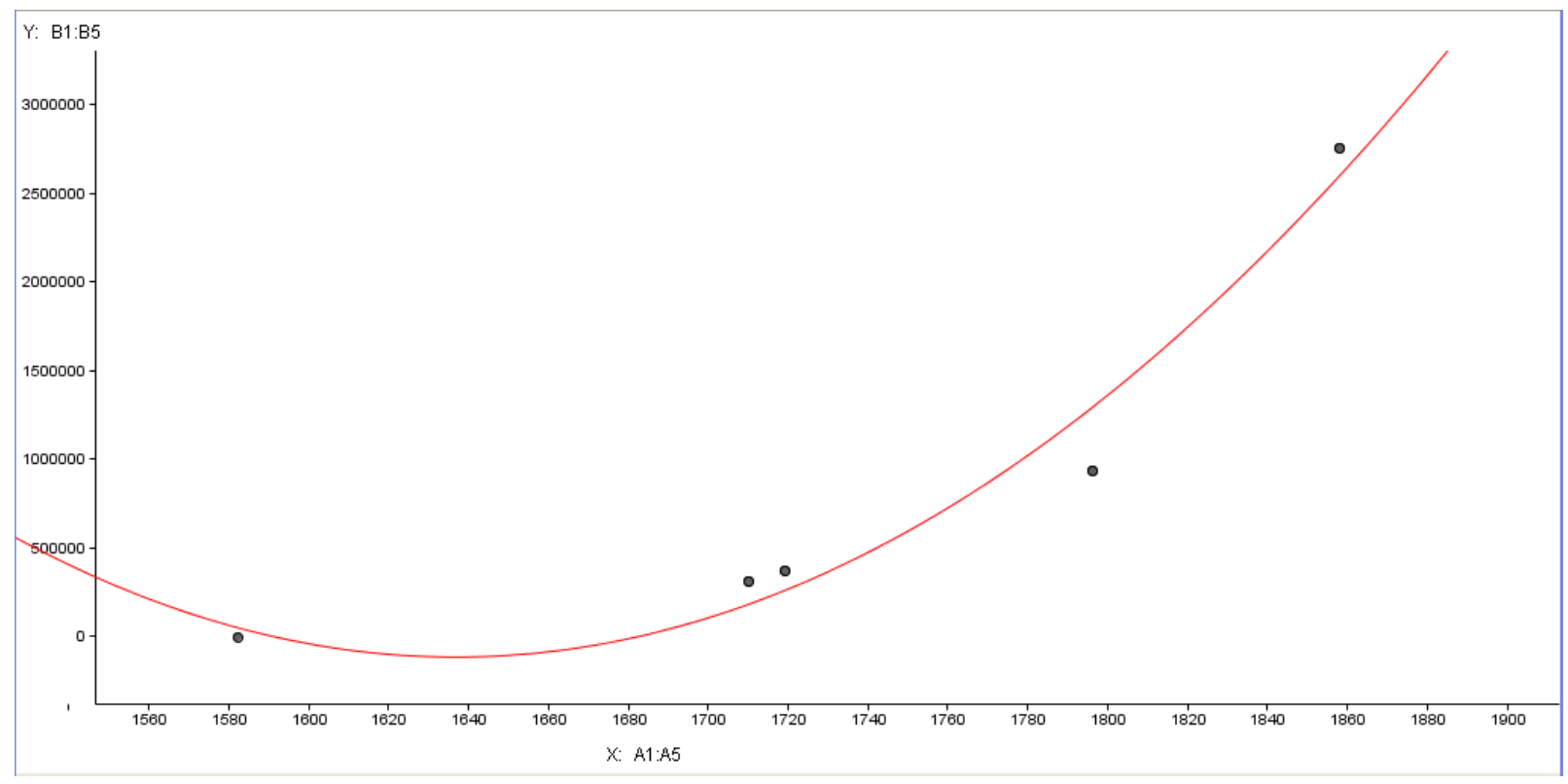

Рис. 12. График уравнения $y=55,5754 x^{2}-181939,3702+14878452,9784$ 


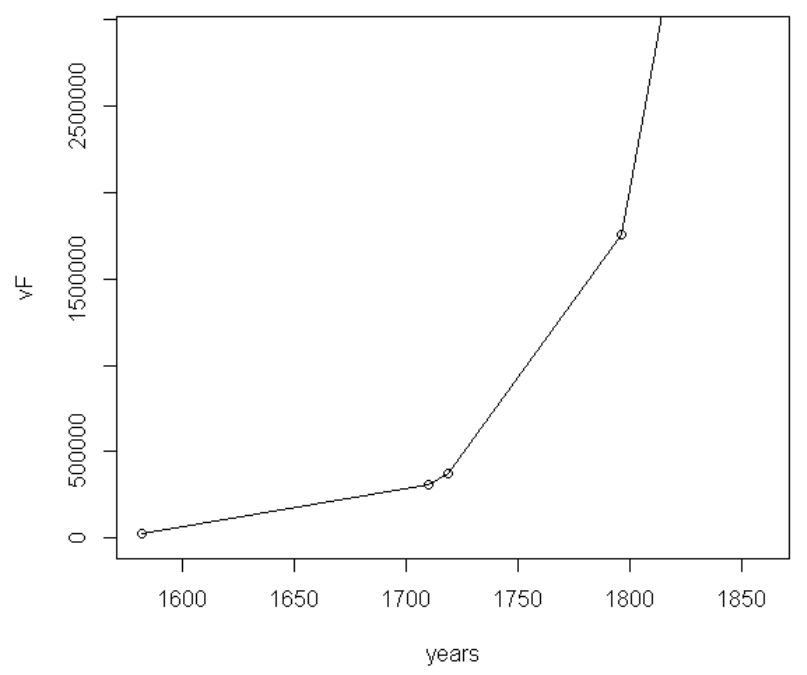

Рис. 13. График функции $y=0,0000000003105 \cdot\left(1,0204^{x}\right)$.

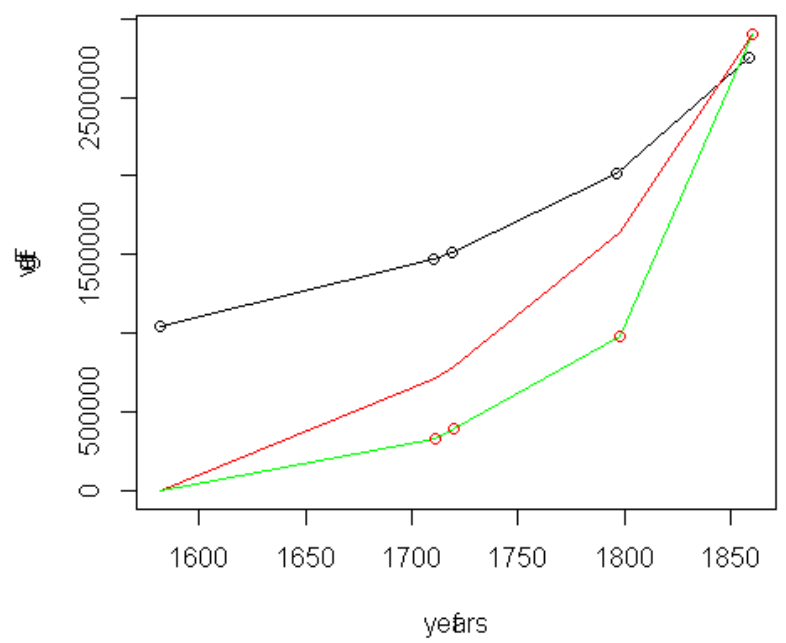

Рис. 14. Модель для уравнения $y=\left(209 \cdot 10^{9} /(2026,87-x)\right) \cdot 0,0021643353142098503$ 